\title{
AN ANALYSIS ON ENGLISH SYLLABLE STRESS PLACEMENTS OF THE ENGLISH STUDY PROGRAM STUDENTS
}

\author{
Siska Veronica \\ Bengkulu University, \\ Siskaveronica17@gmail.com \\ Syafrizal Sabaruddin \\ Bengkulu University, \\ Syafrizal@unib.ac.id \\ Indah Damayanti \\ Bengkulu University, \\ Indah_0789@yahoo.co.id
}

\begin{abstract}
This research concerned with the student's knowledge on the English syllable stress placements of English Education Study Program Students. This research was a descriptive quantitative research. In this research, a test of English syllable placements was used. The words used in the test items were taken from high frequency of word which consist of 10 questions for each English syllable type. The results of this research shows that the knowledge of the English Education Study Program students on English syllable stress placements was low with 39.3 of the total mean score . Futher more, comparison of the test result among three enrollments of samples shows that the different mean score of the second and fourth semester students was not significant ( 0.6 points); while the different mean scores of the second and fourth semester with sixth semester students was significant (20 points).
\end{abstract}

\section{Key words: Syllable, Stress, Syllable Stress, Knowledge.}

\begin{abstract}
Abstrak
Penelitian ini berkaitan dengan pengetahuan siswa tentang penempatan tekanan suku kata bahasa Inggris dari siswa program studi pendidikan bahasa Inggris. Penelitian ini adalah kuantitatif deskriptif. Dalam penelitian inisebuah tes pekanan suku kata bahasa Inggris telah digunakan. Kata-kata yang digunakan dalam soal tes diambil dari frase kata-kata yang tinggi yang terdiri dari 10 pertanyaan untuk setiap tipe suku kata bahasa Inggris. Hasil penelitian ini menunjukkan bahwa pengetahuan siswa program studi bahasa Inggris terhadap penempatan tekanan suku kata bahasa Inggris rendah dengan total skor rata-rata sekitar 39,3. Hasil lain menunjukkan perbedaan nilai rata-rata pada semester kedua dan keempat tidak terlalu signifikan (0,6 poin), sedangkan perbedaan nilai semester kedua dan keempat dengan semester enam adalah signifikan (20 poin).
\end{abstract}

\section{Kata Kunci : Penekanan, Suku Kata, Penekanan Suku Kata, Pengetahuan.}

\section{INTRODUCTION}

The students of the English Education Study Program are role models because they are going to be teachers in the future. As a role model, they should have a good knowledge and skill in speaking, listening, writing and reading. When they speak, pronunciation is one of the most important things that they should master in order to communicate appropriately and fluently to other people. According to Fangzhi (1998, p. 196) "It is important to pay attention to pronunciation since it results in whether or not someone's message can be passed or not by other people". In addition, Richard (2002) stated pronunciation is the sound of 
the language or phonology; stress and rhythm; and intonation.

Students of the English education study program who learn about English language need to know about English stress. Based on the researchers' experience, the students are wrong in placing stress. This is because the material about English syllable stress placements did not have a specific course. It is given in speaking course where sometimes the lectures give some cognition about English syllable stress placements, consequently their knowledge about English syllable stress placements is low. When the English students want to pronounce a word with good pronunciation, they should have a good knowledge about stress. Stress is relative emphasis or prominence given to a certain syllable in a word or to a certain word in a phrase or sentence. It divided into two categories, they are primary and secondary stress, where primary stress is the strongest degree of stress placed on a syllable in the pronunciation of a word and secondary stress is the weaker of two degrees of stress in the pronunciation of a word.

When talking about stress is also talking about syllable and sentence stress. According to Fudge (2015) there are two kinds of stress, they are sentence-stress and syllable-stress. Sentence stress is the manner in which stress is distributed on the word and syllable stress is the manner in which stress is distributed on the syllable. And he also stated there is a sign (') to put stress placement in a word.

English syllable stress placements are important for the English students because every word has different word syllable stress placements. In English Education Study Program, some of students have difficulties in placing stress on a syllable. It was investigated in Sabaruddin and Kurniawan research. In their research the subject are 27 students of seven semesters. They found most of students' pronouncing a word in inappropriate places.
On the other hand, there are some rules of giving stress, but the students did not get intensive material about it. Because of it, the students got difficulties to put stress on the syllable. The students should have good knowledge about English syllable stress placements to make their pronunciation more fluently. As role model, students must be able to speak English with correct pronunciation. Therefore, if the students are wrong in placing stress on the syllable, it will make different meaning of a word, for example the word "dessert and desert", if students stress on the first syllable it means "gurun" but when the students stress on the second syllable, it means "makanan penutup". Besides, English syllable stress placements are important for another job, like; presenter, tour guide, mc and so on.

There were also some researchers who did the research related to this research. First, Sabaruddin and Kurniawan (2016) studied about English stress pattern of words by the students of the English Education Study Program. In this research, they investigated the patterns of English stresses spoken by students of the English Education Study Program and the result was the students are confused and complicated in a word that has more syllable. Second, Toro-Soto, J. M., Rodríguez-Fornells, A., \& SebastiánGallés, N. (2007) analyzed about Stress Placement and Word Segmentation by Spanish Speakers. In this research, they investigated how Spanish speakers put stress in a word. The results showed some stress and syllable information may contribute differently to the segmentation of speech in languages such as Spanish and English. Two kinds of previous study focused on stress placements by spoken or we can say they are focused on skill, but in this research, the researcher focused on the knowledge of the students about English syllable stresses word placement.The studied by Sabaruddin and Kurniawan showed most of English education study program students pronounced a set of 
words with no stress, where $27 \%$ on onesyllable, $10 \%$ on two-syllable, $14 \%$ on three-syllable, and $27 \%$ of four-syllable and also English Education Study Program students pronounced a set of words with multiple stress where $60 \%$ on two-syllable s, $29 \%$ on three-syllable and $45 \%$ of foursyllable but just some of them pronounced a word in the appropriate place. Based on explanation above, the researcher would like to to know the knowledge of English Education Study Program students on English syllable stress placements and the English Education Study Program students' knowledge of different level.

Based on the fact has found, the researcher carried out a research about an analysis on English syllable stress placements of the English study program students which the participant are fourty nine of english study program students. This research is so important because it can help the teachers to know students' knowledge about English syllable stress placemnts.

\section{METHOD}

This research used a descriptive quantitative method. Three academic years of the English Education Study Program was the population of this study. Meanwhile, 49 students was a sample. It is because the theory of Arikunto. He stated, if the population more than one hundred people we can take $20 \%$ of the population.In this research, a test of English syllable placements wads used. The words used in the test items were taken from high frequency of word (Paul Nation: 2007) which consist of 10 questions for each English syllable types. The data of this research was analyzed by using qualitative and quantitative method. The descriptive qualitative method used since the researcher needs to describe the result of the data. On the other hand, quantitative method was used since the researcher was needed to compute the item of test before describing it. In quantitative method, the researcher used S formula and Mean score to get the data.

$S=\frac{C A}{N} X 100$

Where;

$\mathrm{S}=$ Final Test Score

$\mathrm{N}=$ Number of scores

$\mathrm{CA}=$ Number of Correct answer

(Arikunto,

2003)

After knowing the score of the students, the researcher tried to find the mean score of the students for each different enrolment. Calculating the mean score of the students' score by using the following formula:

$$
\bar{X}=\frac{\sum X}{N}
$$

Where;

$\mathrm{X}=$ Mean Score

$\sum X=$ The sum of all score

$\mathrm{N}=$ the total number of subjects

The last, the researcher used the result of mean score to know the differences of students mean score for each enrolment and the researcher will make the graph from it.

\section{RESULT AND DISCUSSION Results}

The data of this research have been collected and analyzed in order to get the description about students' knowledge based on mean score and the differences of the students' knowledge for each enrollment.

\section{Students' Knowledge on English Syllable Stress Placements}

Students knowledge of English syllable stress placements for each enrollments shows in the graph below 
Graph 1. The Knowledge of the English Study

Program Students on English syllable stress placements.

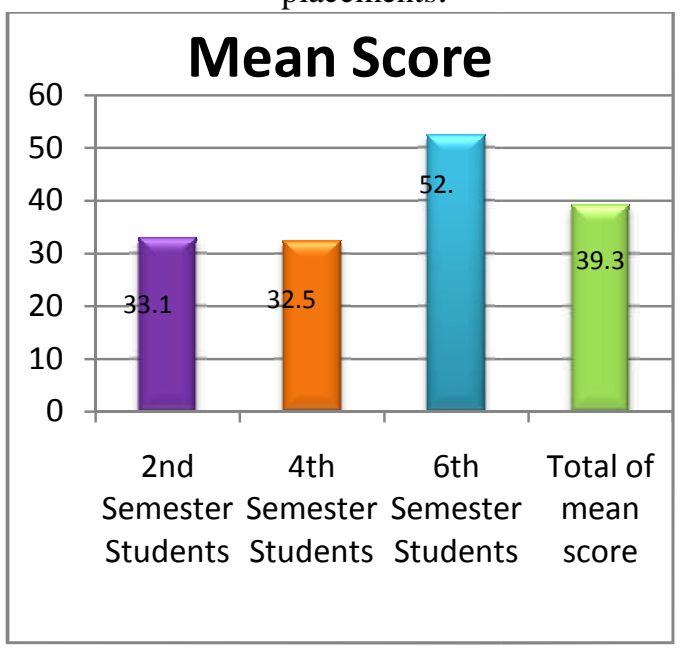

From the mean score above, students in fourth semester get the lowest mean score. On the other hand, the English education study program in the sixth semester achieves the highest mean score. As we can see on the graph, the English Education Study Program students in second semester achieve total score 562 from 17 students as a sample and the mean score is 33.1. Then, the English Education Study Program students in the fourth semester gets the total score 520 which 16 students as a sample and the mean score is 32.5. The last is students in the sixth semester. They have total score 842 which 16 students as the sample and their mean score are 52.5.

Based on a classification score by Arikunto (2003). Arikunto divided classification score into four parts; they are low, average, good and excellent. The students who achieve a score under 50 get low predicate, 50-69 get average predicate, 70-79 get good predicate, and 80-100 get excellent predicate for their knowledge about English syllable stress placements. Therefore, students in second and fourth semester have low predicate for their knowledge on the English syllable stress placements. On the other hand students in sixth semester have average predicate for their knowledge on the English syllable stress placements. For the conclussion there is influence of English Education Study Program enrollments with their knowledge on the English syllable stress placements. However, the influence is not significant and also the result of the total mean score for all of English Education Study Program students shows their knowledge about English syllable stress placements is Low. It is because their total mean score only 39.3 .

\section{A Comparison of Correct Answer} among Three Enrollments with the Result among Five Types Syllable Stress

In this part, the researcher describes the result of students answer for five types of syllable stress. It helps the researcher to know the differences of students answer in three enrollments.

Graph 2: The result of students answer for five types of syllable stress.

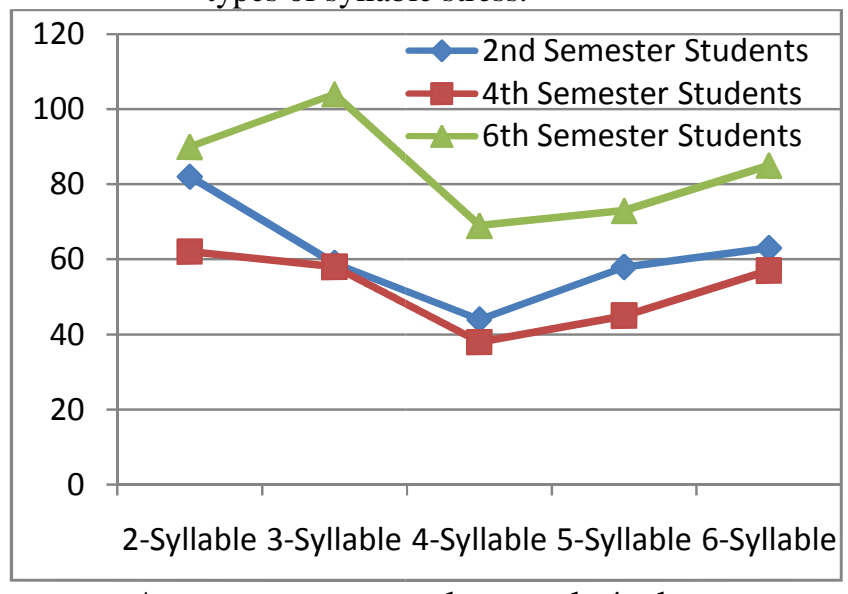

As we can see on the graph 4, there are differences in the total correct answer in five types of syllable stress for each enrollment. In second and fourth semester students, the highest correct answer appear on 2-syllable. On the hand, in sixth semester students the highest correct answer appear on 3-syllable. Meanwhile, the lowest correct answer in three enrollements appear on 4-syllable.

\section{Mean Score Comparison Among Different Enrolments}

In this part the researcher uses the result of mean score for each enrollment 
by using graphs to describe the differences of mean score for each enrollment itself.

\section{Diagram for Students Mean Score}

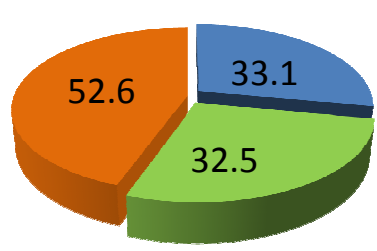

- Second Semestı Students Fourth Semeste Students - Sixth Semester Students

From the diagram above, the mean score of the second semester students is higher than fourth semester. As we can see from the diagram, the difference of total mean score in a second and fourth semester is 0.6 points. There in no significant difference of total mean score in second and fourth semester students. On the other hand, the different mean score of the second and fourth semester with sixth semester students is 20. By looking the total mean score for each enrollment, English Education Study Program students in the second and fourth semester have a low predicate for their knowledge about English syllable stress placements. Meanwhile, the students in sixth semester have average knowledge of their knowledge about English syllable stress placements. The classification knowledge is based on table 1 page 24 .

By looking at the different mean score from the graphic above, the researcher summaries; firstly, sixth semester students achieve first position with predicate average knowledge of English syllable stress placements. Secondly, second semester students get second position with predicate low knowledge of English syllable stress placements. And the last position is fourth semester students with low predicate for their knowledge of English syllable stress placements.

\section{Discussion}

From the data presented in the result, the students of the English Education Study Program in second and fourth semester got
Low knowledge about English syllable stress placements. On the other hand, the sixth semester students got Average knowledge about the English syllable stress placements. It is obtained by the total score of the students in English syllable stress placements.

By looking the graph 1 pages 26, the English Education Study Program students earned the most correct answer occured in 2-syllable, while the most incorrect answer occured in 4-syllable with /ion, /ry, and /ty. This finding is similar with the previous research by Aladeyomi's (2013). In his research, he found the students the most inccorrect answer occured on a word ending /ion, /ic, /ry , /al and /ty. This result was same with this research, where the most wrong answer appeared in 4-syllable which consist of words ending /ion, /ty and /ry. However, contrasted to Aladeyomi's research, in this research the English Education Study Program students in the University of Bengkulu did not get the most inccorrect answer with words ending with /al. It was shown in the number of correct answers of the students in five and six syllables. Where, they had the total of correct answers in five and six syllables higher than four syllables (see on pages 29 tables 3). In Aladeyomi research, he did the research for Learner of English as a second language. Even though in this research the samples were learners of English as a foreign language, but the result remains the same.

On the other hand, by looking at the detailed answer of the students. This result had a correlation with Sabaruddin and Kurniawan. In their research, they found $60 \%$ students pronounced a word with multiple stress in two syllables, some of them pronounce in inappropriate places, for example the word that should be pronounced in the first syllable they pronounce in the second syllable. It was the same with with the answer of the second and the fourth semester students in two syllables (question number 1-10). 
They chose an answer on word that have multiple stress. Multiple stress is a word where both syllable given stress, for example, trans-port. In fact, that was the wrong answer, but most of them chose words that have multiplte stress. Contrasted to sixth semester students, there was no one of them chose words that have multiplte stress.

Next, the mean score of the second semester students was higher than the fourth semester students (0.6 points). While the different mean score of the second and fourth semester with sixth semester students was 20 points. From the different mean score of the second and fourth semester students, the researcher concluded that the students at higher semester did not represent their knowledge of English syllable stress placements. It means, the student enrollments did not give the significant influence in their English syllable stress placements knowledge. This result was supported by theory of Notoatmojo (2007). In his theory, he stated there are three important factors resulted in someones's knowledge in learning. They were environment, family and friends. While, the others supporting factors that affect in someone's knowledge were education, mass media, experience and age.

By looking at the phenomena above, the researcher concluded some facts related to the problem. Firstly, the knowledge of English Education Study Program students was low because of there was not any specific courses on English syllable stress placement. That is why, it is really important to insert the material about English syllable stress placements for English Education Study Program. As a theory by Hop (2009), pronunciation or stress in a word or sentence is really important to avoid negative impression, misunderstanding and ineffective communication. Therefore, as a role model, English students should have good pronunciation or stress of a word and sentence to avoid it. On the other hand,
Chyntia (2013) explain four important categories to be a professional English teacher. The first category was the teacher must be able to pronounce English correctly. The second category was the teacher must have the ability to speak English correctly. The third category was the teacher must know and speak observing correct intonation and stress pattern. The last category was the most important thing that a teacher must have.

Secondly, the knowledge of English Education Study Program students was low because of the influence of mother tongue. As Kozok (2011) stated that Indonesian stress was on the word not in the syllable. As we know, mother tongue give effect to the language that we learn and there was not any stresses on the syllable of our native language. That is why the students were difficult to give a stress toward English word.

\section{CONCLUSION AND SUGGESTION}

The conclutions of this research are: firstly, based on the total mean score, the knowledge of the English Education Study Program students at the University of Bengkulu on English syllable stress placements were not high. The total mean score is 39.3 , where with the mean score of second semester is 33.1 with a low predicate for their knowledge about English syllable stress placements. Then, the mean score of fourth semester is 32.5 , they got low predicate for their knowledge of English syllable stress placements and the mean score of sixth semester is 52.5 with an average predicate for their knowledge of English syllable stress placements.

Secondly, for the different the English Education Study Program Students mean score, there is not much difference of mean score between second and fourth semester. It means, it does not really represent the level of their knowledge. Therefore, there is more difference of mean score between second and fourth semester with sixth semester. 
The different mean score of the second and fourth semester is about 0.6 points, while the difference means scores of the second and fourth semester with sixth semester is about 20 points. Which means sixth semester students is much more better than second and fourth semester student's knowledge of English syllable stress placements.

\section{Suggestion}

For the students, the students should practice in placing the stress of the words because the English Education Study Program students are a role model of teacher. The English study program student should have good knowledge and skill about English syllable stress placements in order to be a professional teacher.

For the lecturers, they should be a model for the students. This research had given the information about knowledge of the English Education Study Program students in English syllable stress placements. The result shows all of them have Low knowledge about the English syllable stress placements. It is because of their total mean score is under 50. Based on the information above the lecturer or teacher will be able to insert material about English syllable stress placements in classroom activity.

For the English Education Study Program, they can add a course like pronunciation practice in the English education study program.

For future researcher, the researcher expects the next researcher to conduct a research by looking background of the students. It is because, in this research, the researcher take the samples randomly without knowing the background of the students. On the other hand, the researcher also hope the next researcher to focus on students' skill of English syllable stress placement.

\section{REFERENCES}

Aladeyomi, A.S. (2013). Some stress placement clues of learners of English as a second language. Britih Journal of Arts and Social Sciences, 13(11), 219-230.

Arikunto, S. (2003). Metodologi Penelitian. Jakarta : Rhineka Cipta.

Chynantia. (2013). Profesional Teacher. Dip TESOL Journal, 2 (1).

Fangzhi, Cheng. 1998. The Teaching of Pronunciation to Chinese Students of English. China. 39.

Fudge, E. (2015). English wordstress.New York. Routledge

Kozok, U. (2011). Bahasa Kita. Jakarta: warung cinema.

Nation, P. (2007). Teaching and Learning Vocabulary. Cambridge, UK: Cambridge University Press.

Notoatmodjo, S. (2007). Definisi Pengetahuan Serta Faktor-faktor Yang Mempengaruhi Pengetahuan. Avalable:(http://duniabaca. com/definisi-pengetahuansertafaktor-faktor-yang-mempengaruhipengetahuan. Html. diakses tanggal 13 maret 2014).

Richards, J. C (2002). Methodology in language teaching: An anthology of current practice. Cambridge university press.

Sabarudin, S,.\& Kurniawan, I,. (2016). A descriptive analysis of english stress pattern of word by students of the english education study program, the university of Bengkulu. Symposium of Internatinal Languages \& Knowledge, (pp,217-221).

Toro-Soto, J. M., Rodríguez-Fornells, A., \& Sebastián-Gallés, N. (2007). Stress Placement and Word Segmentation by Spanish Speakers. Psicologica: International Journal of Methodology and 
Experimental Psychology, 28(2),

167-176. 